\title{
Calonectria scoparia and Calonectria morganii sp. nov., and variation among isolates of their Cylindrocladium anamorphs
}

\section{P. W. CROUS}

Department of Plant Pathology, University of Stellenbosch, 7600 Stellenbosch, South Africa

\section{A. C. ALFENAS}

Departemento de Fitopatologia da Universidade Federal de Viçosa, 36570 Viçosa, Brasil

\section{J. WINGFIELD}

Department of Microbiology and Biochemistry, University of the Orange Free State, P.O. Box 339, 9300 Bloemfontein, South Africa

Cylindrocladium scoparium and C. candelabrum are important pathogens of numerous hosts with wide geographical distributions. Single-conidial pairings of 48 isolates tentatively identified as either C. scoparium or C. candelabrum from Brazil, North America and South Africa have confirmed that at least two distinct species exist within this complex. These results were also confirmed with total protein discontinuous SDS-PAGE electrophoresis gels. The two species could also be distinguished morphologically on their vesicle morphology. C. candelabrum is accepted as the correct name for Brazilian and South African isolates with ellipsoidal to obpyriform apical vesicles (widest below the middle). North American and some Brazilian isolates with ellipsoidal to pyriform apical vesicles (widest above the middle) represent C. scoparium, with C. ellipticum and C. brasiliensis as synonyms. Calonectria morganii is newly described as the teleomorph of Cylindrocladium scoparium. Calonectria scoparia is shown to be the teleomorph of Cylindrocladium candelabrum.

Cylindrocladium scoparium Morgan is the type of Cylindrocladium Morgan (Morgan, 1892). This fungus is known from numerous collections worldwide (Booth \& Gibson, 1973; French \& Menge, 1978; Peerally, 1991). It is reported to cause a wide range of disease symptoms including damping off, root rot, cutting rot, stem cankers, and leaf-spot, as well as seedling and shoot blight (Cordell \& Rowan, 1975; Cordell \& Skilling, 1975; Ferreira, 1989). C. scoparium has also been reported to occur on an extensive range of hosts (Bertus, 1976; French \& Menge, 1978; Peerally, 1991). C. candelabrum was originally described from the leaves of a Luma sp. in Brazil (Viegas, 1946). In contrast to the frequently cited C. scoparium, the only other reference found in the literature referring to $C$. candelabrum was that of Peerally (1991), who considered C. candelabrum to be the earlier name for C. ellipticum Alfieri, Seymour \& Sobers.

When C. scoparium was first described from a dead pod of honey locust (Gleditsia triacanthos L.) in Ohio, the exact nature of the stipe and the vesicle was omitted from the description (Morgan, 1892). Subsequent studies on the C. scoparium group have reported the apical vesicle to be ovoid to ellipsoidal (Sobers \& Seymour, 1967), and inequilaterally obovoid (Booth \& Gibson, 1973). Currently, some workers accept vesicle morphology as one of the most important taxonomic criteria to separate species of Cylindrocladium (Sobers, 1968; Peerally, 1973; El-Gholl et al., 1986; El-Gholl, Leahy \& Schubert, 1989; Peerally, 1991), while others (Hunter \& Barnett, 1978;
Rossman, 1983) report it to be highly variable. Recent studies (Crous, Phillips \& Wingfield, 1992) have found, however, that this criterion is reliable when examined on carnation-leaf agar (CLA) (Fisher et al., 1982; Crous et al., 1992) under predetermined conditions of incubation.

The concept of $C$. scoparium as a species has developed to such an extent that isolates were placed in this taxon if conidia were 1-septate, 33-59 $\times 3-4 \mu \mathrm{m}$, and apical vesicles were oval to ellipsoid to umbonate (Peerally, 1991). In contrast, the apical vesicles of $C$. candelabrum, however, were illustrated as ellipsoidal, while conidia were described as 1-septate, 40-88 × 5-6 $\mu \mathrm{m}$ (Viegas, 1946).

Sobers (1974) reported a Calonectria teleomorph for $C$. scoparium after ascocarps with fertile ascospores developed from pairings of single-conidial isolates from different locations. The Calonectria teleomorph was not named. Using different isolates, the experiment was repeated by Ribeiro (1978), who found that a teleomorph resulted from pairing different Brazilian isolates. The name Calonectria scoparia Ribeiro \& Matsuoka was proposed for the teleomorph of Cylindrocladium scoparium (Ribeiro, 1978). Although reference is made to a holotype specimen lodged at Viçosa, Brazil (VIC), no such specimen could be located in the present study. Ribeiro (1978) did not publish the work from his thesis, and Peerally (1991) provided a Latin description to validate the name Calonectria scoparia Ribeiro \& Matsuoka ex Peerally.

The aim of the present study was to reconsider the species 
Table 1. Isolates of Cylindrocladium candelabrum and C. scoparium used in total protein electrophoretic studies

\begin{tabular}{|c|c|c|c|c|c|c|}
\hline & Vesicle morphology & Source & Origin & Collector & Accession no. & Position \\
\hline \multirow[t]{5}{*}{ C. candelabrum } & $\begin{array}{c}\text { Elliptical to } \\
\text { pyriform }\end{array}$ & Eucalyptus sp. & Natal, R.S.A. & M. J. Wingfield & PPRI 4202 & 1 \\
\hline & & Eucalyptus sp. & $\begin{array}{l}\text { Eastern Transvaal, } \\
\text { R.S.A. }\end{array}$ & P. W. Crous & PPRI 4199 & 2 \\
\hline & & Eucalyptus sp. & $\begin{array}{l}\text { Virginopolis, } \\
\text { MG, Brazil }\end{array}$ & A. C. Alfenas & PPRI 4146 & 3 \\
\hline & & Eucalyptus sp. & $\begin{array}{l}\text { Caronel Fabricano, } \\
\text { MG, Brazil }\end{array}$ & A. C. Alfenas & PPRI 4163 & 4 \\
\hline & & Eucalyptus sp. & $\begin{array}{l}\text { São Mateus, } \\
\text { ES, Brazil }\end{array}$ & A. C. Alfenas & PPRI 4161 & 5 \\
\hline \multirow[t]{6}{*}{ C. scoparium } & $\begin{array}{l}\text { Elliptical to } \\
\text { obpyriform }\end{array}$ & Eucalyptus sp. & U.S.A. & A. Rossman & PPRI 4154 & 6 \\
\hline & & Mahonia sp. & Florida, U.S.A. & S. A. Alfieri & ATCC 38227 & 7 \\
\hline & & Leucothoe sp. & $\begin{array}{l}\text { North Carolina, } \\
\text { U.S.A. }\end{array}$ & D. M. Benson & ATCC 46300 & 8 \\
\hline & & Anacardium sp. & $\begin{array}{l}\text { Fortaleza, } \\
\text { CE, Brazil }\end{array}$ & D. O. Freire & PPRI 4731 & 9 \\
\hline & & Rhododendron sp. & $\begin{array}{l}\text { Gainsville, } \\
\text { U.S.A. }\end{array}$ & C. R. Semer & PPRI 4144 & 10 \\
\hline & & Eucalyptus sp. & Brazil & T. R. Ciferri & CBS 230.51 & 11 \\
\hline
\end{tabular}

concept in C. scoparium and C. candelabrum, by studying isolates collected from Brazil, North America and South Africa. Sexual compatibility between isolates identified as either C. scoparium or C. candelabrum was also tested. Furthermore, variation in morphology of isolates from these countries was considered. A comparison was also made with isolates of the suspected synonyms, C. brasiliensis (Batista \& Ciferri) Peerally and C. ellipticum, using morphological as well as total protein banding patterns.

\section{MATERIALS AND METHODS}

\section{Morphology}

Single-conidial isolates were subcultured on to CLA, incubated at $25^{\circ} \mathrm{C}$ under nuv light and examined after $7 \mathrm{~d}$ (Crous et al., 1992). Only material occurring on the carnation tissue was examined. Averages of all measurements are given in parentheses. Perithecia were examined before they became papillate and exuded spore masses. They were placed in $5 \%$ $\mathrm{KOH}$ for $2-12 \mathrm{~h}$, fixed in 5\% glutaraldehyde for $12-24 \mathrm{~h}$ and subsequently washed in $\mathrm{H}_{2} \mathrm{O}$ and placed in a gelatin solution ( $12.5 \mathrm{~g}$ gelatin, $27.5 \mathrm{~g} \mathrm{H}_{2} \mathrm{O}, 0.5 \mathrm{~g}$ phenol). Longitudinal sections $(10-15 \mu \mathrm{m})$ were made through perithecia using a Leitz Kryomat 1703 freezing microtome. Squash mounts were prepared in lactophenol cotton blue and $3 \%$ aqueous $\mathrm{KOH}$. Abbreviations used for herbaria are those cited by Holmgren \& Keuken (1974). Cultures and specimens examined were lodged with the National Collection of Fungi, Pretoria (PREM), and are maintained in the culture collection of the Department of Plant Pathology, University of Stellenbosch, Stellenbosch.

Validly described species in Cylindrocladium that are reported to have similar vesicle morphologies and I-septate conidia were compared with isolates of $C$. scoparium and $C$. candelabrum. Where possible, they were also paired with all isolates used in this study. The species compared were $C$. brasiliensis (CBS 230.51, type culture; IMI 43688, type specimen) and C. ellipticum (ATCC 38227, type culture).

\section{Sexual compatibility}

Forty-eight single-conidial isolates (listed under cultures examined) including 19 from Brazil, 7 from North America and 22 from South Africa, were paired with each other in all possible combinations. Pairings were made on plates of CLA. Single-conidial isolates were grown on $2 \%$ malt-extract agar for $7 \mathrm{~d}$ at $25^{\circ}$ under nuv light. Agar discs (3 mm diam.) from the periphery of the actively growing colonies were used to inoculate plates. In all pairings, two isolates were placed on opposite sides of a piece of carnation leaf. There were four pieces of carnation leaf per plate, three replicate plates per pairing, and the experiment was repeated once. Plates were sealed with a double layer of Parafilm, placed under nuv light at $25^{\circ}$ and examined weekly until perithecia developed.

\section{Total protein electrophoresis}

Single-conidial isolates (Table 1) were compared electrophoretically on the basis of their total soluble protein banding patterns. Isolates were grown on $2 \%$ malt-extract agar (MEA), and plugs from seven-d-old cultures transferred to $500 \mathrm{ml}$ Erlenmeyer flasks (six/isolate), containing $100 \mathrm{ml}$ glucoseyeast extract broth (Zumpetta, 1976), and incubated for $7 \mathrm{~d}$ in the dark at $25^{\circ}$. Mycelium was extracted, and macerated in $0.1 \mathrm{M}-\mathrm{Na}_{2} \mathrm{HPO}_{4}-\mathrm{KH}_{2} \mathrm{PO}_{4}$ buffer ( $\mathrm{pH} 7 \cdot 0$ ) (lysing buffer), and filtered. The extract was centrifuged at $10000 \mathrm{~g}$ for $7 \mathrm{~min}$, the supernatant extracted, and dialysed in de-ionized $\mathrm{H}_{2} \mathrm{O}$. The dialysed supernatant was freezer-dried, and stored under vacuum. Proteins were resuspended in lysing buffer and the concentrations determined (Biorad protein assay kit). A volume equivalent to $60 \mathrm{\mu g} \mathrm{ml}^{-1}$ was layered on to the gel. A rainbow protein molecular weight kit (Amersham Inter- 

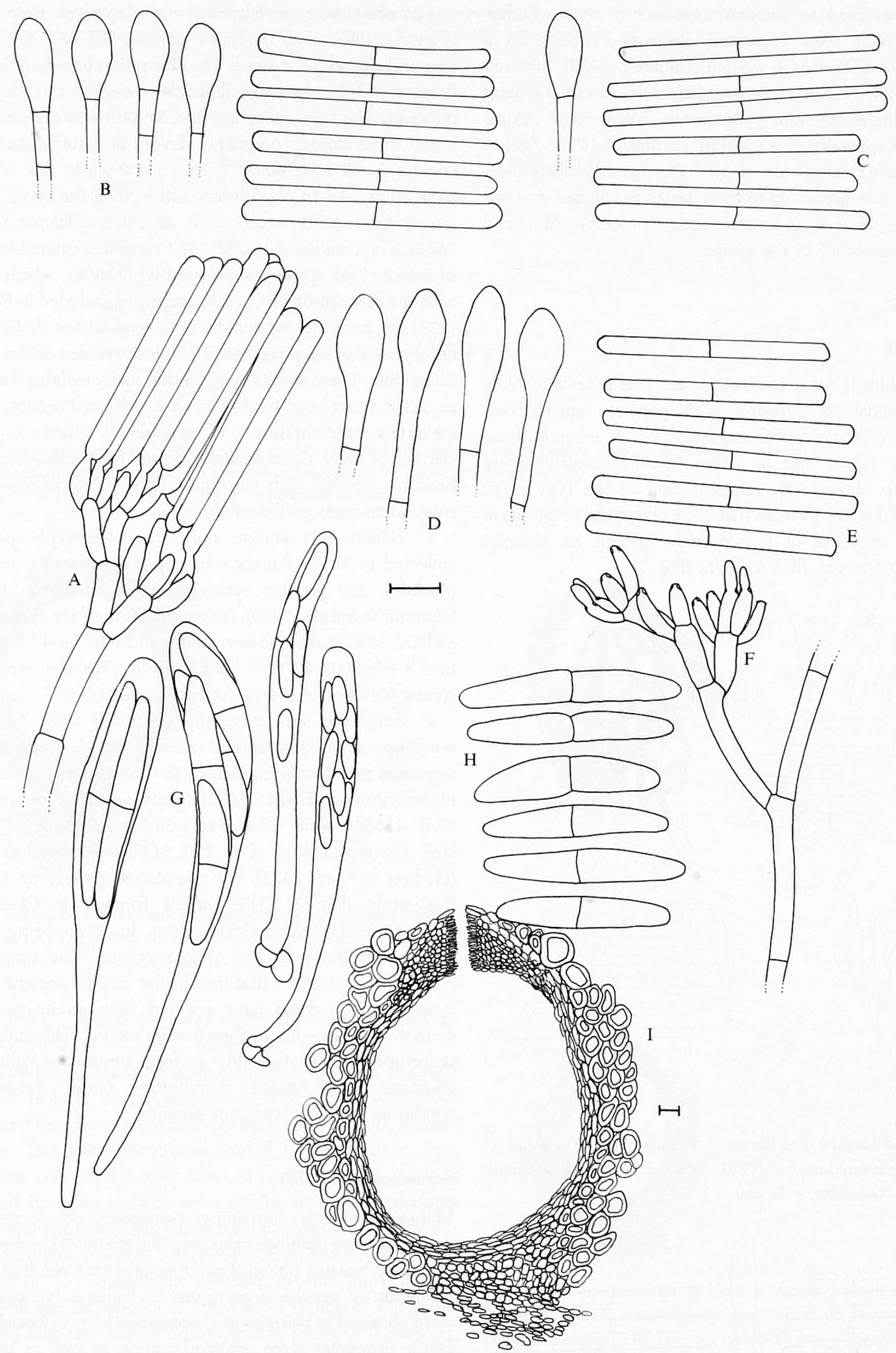

Fig. 1. Calonectria morganii and its Cylindrocladium anamorph. A, Conidiophore; B, vesicles and conidia (BPI 414576, lectotype); C, vesicle and conidia on CLA (ATCC 38227, type culture of C. ellipticum); D, vesicles; E, conidia; F, conidiophore on CLA (ATCC 46300); G, immature and mature asci of Calonectria morganii (PREM 51042); H, ascospores (bar $=10 \mu \mathrm{m}$ ); I, vertical section through a perithecium $(b a r=20 \mu \mathrm{m})$. 
national) was used as standard reference proteins. Buffersoluble proteins were separated electrophoretically on a discontinuous SDS-PAGE system (Laemmli, 1970), buffered with $0.1 \mathrm{M}$-Tris- $\mathrm{HCl}(\mathrm{pH} 6 \cdot 8-8 \cdot 8)$. Gels were run on a Hoefer SE 6000 (Hoefer Scientific Instruments, Tokai, South Africa) vertical slab apparatus at a constant current of $10 \mathrm{~mA} / \mathrm{gel}$ at $10^{\circ}$. Gels were stained with $10 \mathrm{~g} \mathrm{l}^{-1}$ Coomassie brilliant blue. One isolate was grown up in three separate batches, and run on the same, as well as separate gels to confirm intra- and intergel repeatability of the system.

\section{RESULTS}

\section{Morphology}

Vesicles of North American isolates and one Brazilian isolate were ellipsoidal to pyriform with papillate apices, corresponding to the type of $C$. scoparium (Fig. 1), whereas those from South Africa and all other Brazilian isolates were ellipsoidal to obpyriform, corresponding to the type of $C$. candelabrum (Fig. 2). Vesicles that were ellipsoidal to pyriform are typical of those of $C$. scoparium present on material collected by Morgan (BPI 414576) (Fig. 1).

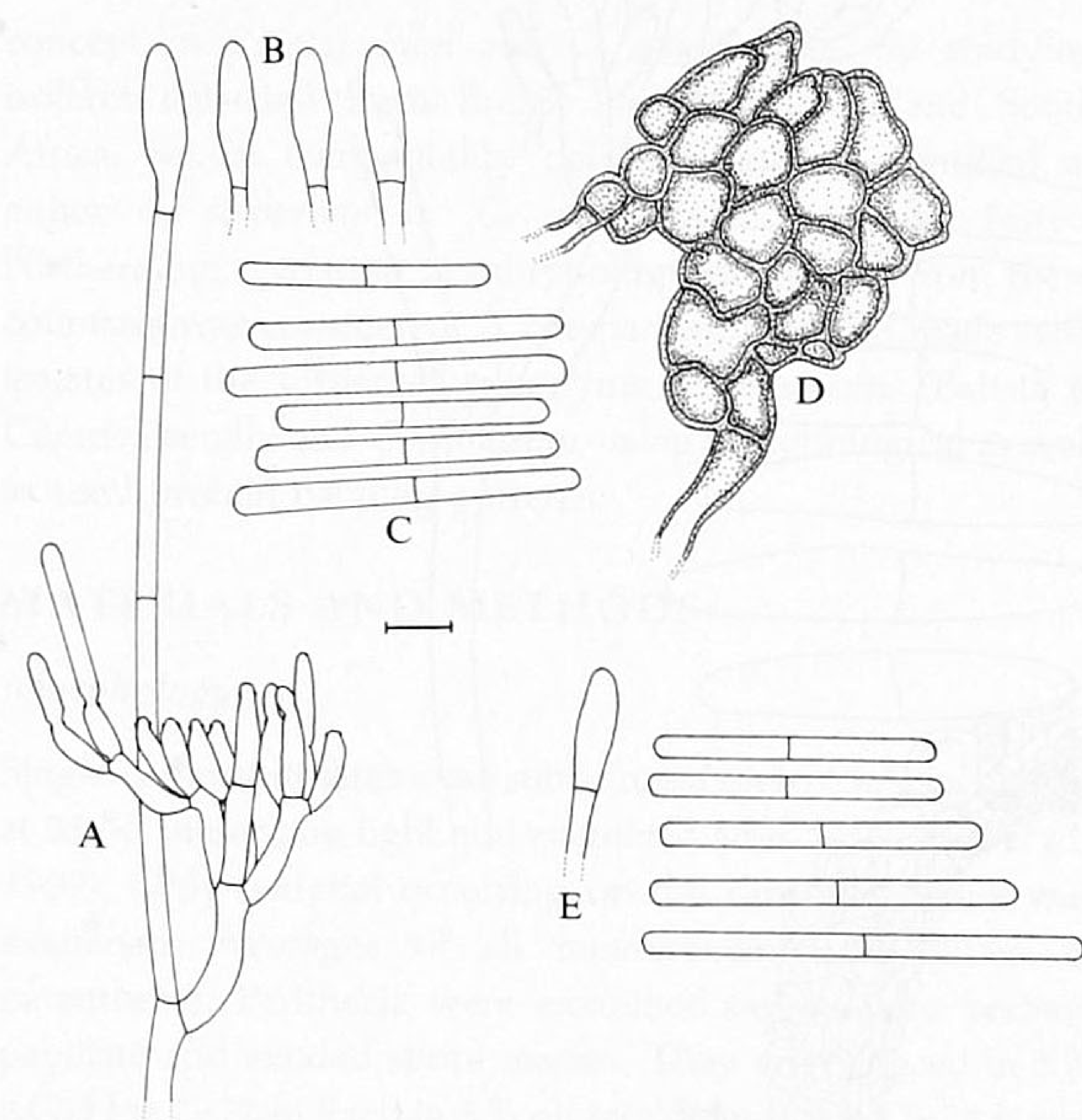

Fig. 2. Cylindrocladium candelabrum. A, Conidiophore; B, vesicles; C, conidia; D, chlamydospores (PPRI 3989); E, vesicle and conidia (IACM, 440, type) $($ bar $=10 \mu \mathrm{m})$.

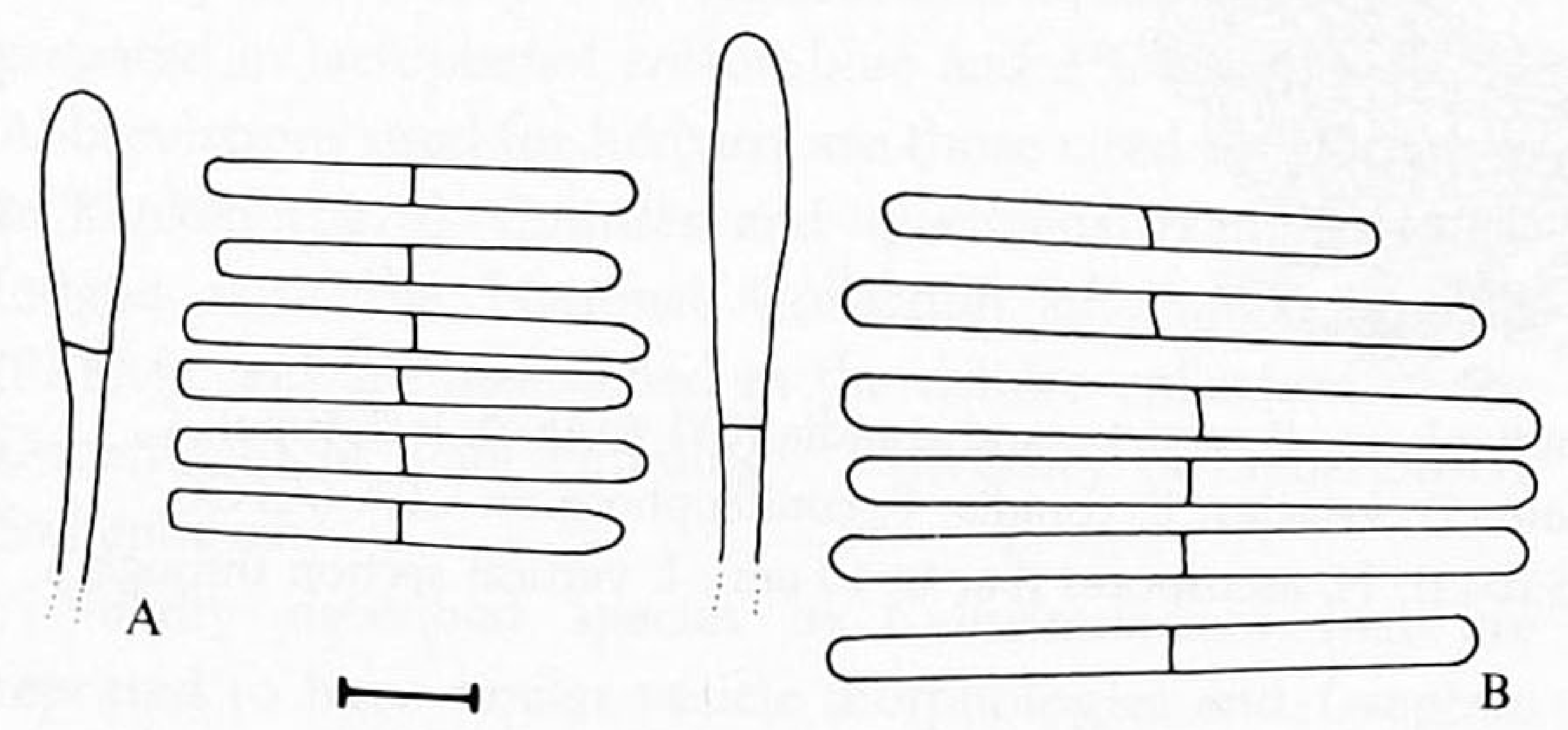

Fig. 3. Cylindrocladium brasiliensis. A, Obovoid to clavate vesicle and conidia (IMI 43688, type specimen); B, conidia on CLA (CBS 230.51, type culture).
Cylindrocladium candelabrum was described from Brazil (Viegas, 1946), with 1-septate conidia, 40-88 $\times 5-6 \mu \mathrm{m}$ in size, and ellipsoidal vesicles. The illustration based on the type (Viegas, 1946) showed ellipsoidal vesicles and doliiform phialides. The type collection (IACM 440) was examined and found to be almost completely devoid of material, but those conidia found were $46.0-70.0 \times 3.5-5.0 \mu \mathrm{m}$ in size. Vesicles were ellipsoidal to obpyriform. Other than the type, Viegas also lodged another collection of C. candelabrum (IACM 2682). The conidia of IACM 2682 were determined to be 5septate and the apical vesicles narrowly clavate, which agrees with the description of $C$. quinqueseptatum included in Peerally (1991). In contrast, the conidia of C. candelabrum (IACM 440, holotype) are 1 -septate and the apical vesicles wider below the middle. These results suggest that many isolates that have in recent years been treated as C. scoparium (Peerally, 1991), are in fact representative of $C$. candelabrum. In order to ensure clarity, the name C. candelabrum is used for South African and Brazilian isolates with ellipsoidal to obpyriform vesicles in subsequent parts of this study.

C. ellipticum is known only from the type specimen collected in North America, having larger conidia, reniform phialides, and smaller vesicles than C. scoparium (Alfieri, Seymour \& Sobers, 1970). An examination of the type culture (ATCC 38227) (Fig. 1) revealed conidia to be $47 \cdot 0-(53 \cdot 5)$ $66.5 \times 3.5-(4.0)-4.5 \mu \mathrm{m}$. Vesicles and phialides were also similar to those of North American isolates of C. scoparium.

C. brasiliensis was originally described from Eucalyptus seedlings as a small-spored variety of $C$. scoparium ( $C$. scoparium var. brasiliensis Batista \& Ciferri) with a noticeably higher virulence (Batista, 1951). Conidia on the type specimen (IMI 43688) were $25.0-(31.5)-34.0 \times 2.5-(3.0)-3.5 \mu \mathrm{m}$ in size. The type culture (CBS 230.51) was reported as sterile (Hodges \& May, 1972), but sporulated sparsely on CLA in this study (Fig. 3). The conidia formed on CLA were $39.0-(45.0)-51.0 \times 3.0-(3.5)-4.0 \mu \mathrm{m}$ in size, being much larger than those on the type specimen. The opinion of Alfenas et al. (1979) - that the smaller conidia present on the type specimen could have resulted from an inappropriate growth medium - might therefore be correct. This isolate has unfortunately lost its ability to form vesicles in culture, so comparisons of vesicle morphology under standardized conditions on CLA were not possible.

\section{Sexual compatibility}

Mature perithecia containing ascospores developed after $8 \mathrm{wk}$, and were obtained from only 9 of the 1176 combinations of the 48 isolates paired. Paired isolates that resulted in the formation of perithecia are given in Table 2. No perithecia were obtained in pairings of C. scoparium with C. candelabrum. Fertile progenies were obtained among as well as between Brazilian and South African isolates of C. candelabrum (Figs 4, 5). Compatible isolates that produced protoperithecia when incubated alone were considered positive $(+)$, and those that fertilized them as negative $(-)$.

Of the seven North American isolates of C. scoparium tested, one pairing produced fertile perithecia, namely ATCC $46300(+) \times$ ATCC $38227(-)$. The same North American 
Table 2. Single conidial pairings within isolates of Cylindrocladium candelabrum and C. scoparium which resulted in the formation of fertile perithecia ${ }^{1}$

\begin{tabular}{|c|c|c|c|c|c|c|c|c|c|c|c|}
\hline & & \multicolumn{7}{|c|}{ C. candelabrum } & \multicolumn{3}{|c|}{ C. scoparium } \\
\hline & & \multicolumn{4}{|l|}{ Brazil } & \multicolumn{3}{|c|}{ South Africa } & \multicolumn{2}{|c|}{ North America } & \multirow{2}{*}{$\frac{\text { Brazil }}{(-)^{2}}$} \\
\hline \multirow[t]{3}{*}{ t } & & $(+)$ & $(-)$ & $(-)$ & $(-)$ & $(+)$ & $(-)$ & $(-)$ & $(+)$ & $(-)$ & \\
\hline & & PPRI & PPRI & PPRI & PPRI & PPRI & PPRI & PPRI & ATCC & ATCC & PPRI \\
\hline & Accession no. & 4153 & 4161 & 4163 & 4146 & 4202 & 4199 & 4198 & 46300 & 38227 & 4731 \\
\hline
\end{tabular}

PPRI 4153

PPRI $4161 \quad+{ }^{3}$

PPRI 4163

PPRI 4146

PPRI 4202

PPRI 4199

PPRI 4198

ATCC 46300

ATCC 38227

PPRI 4731

$\begin{array}{llll}+ & \cdot & & \\ + & \cdot & \cdot & \\ . & \cdot & \cdot & + \\ . & . & \cdot & +\end{array}$

1 Pairings were done on carnation-leaf agar at $25^{\circ}$ under nuv light and included 48 isolates paired in all possible combinations.

2 Information pertaining to isolates screened is presented in the cultures examined section.

$3+$. Fertile perithecia formed; ., no fertile perithecia formed.
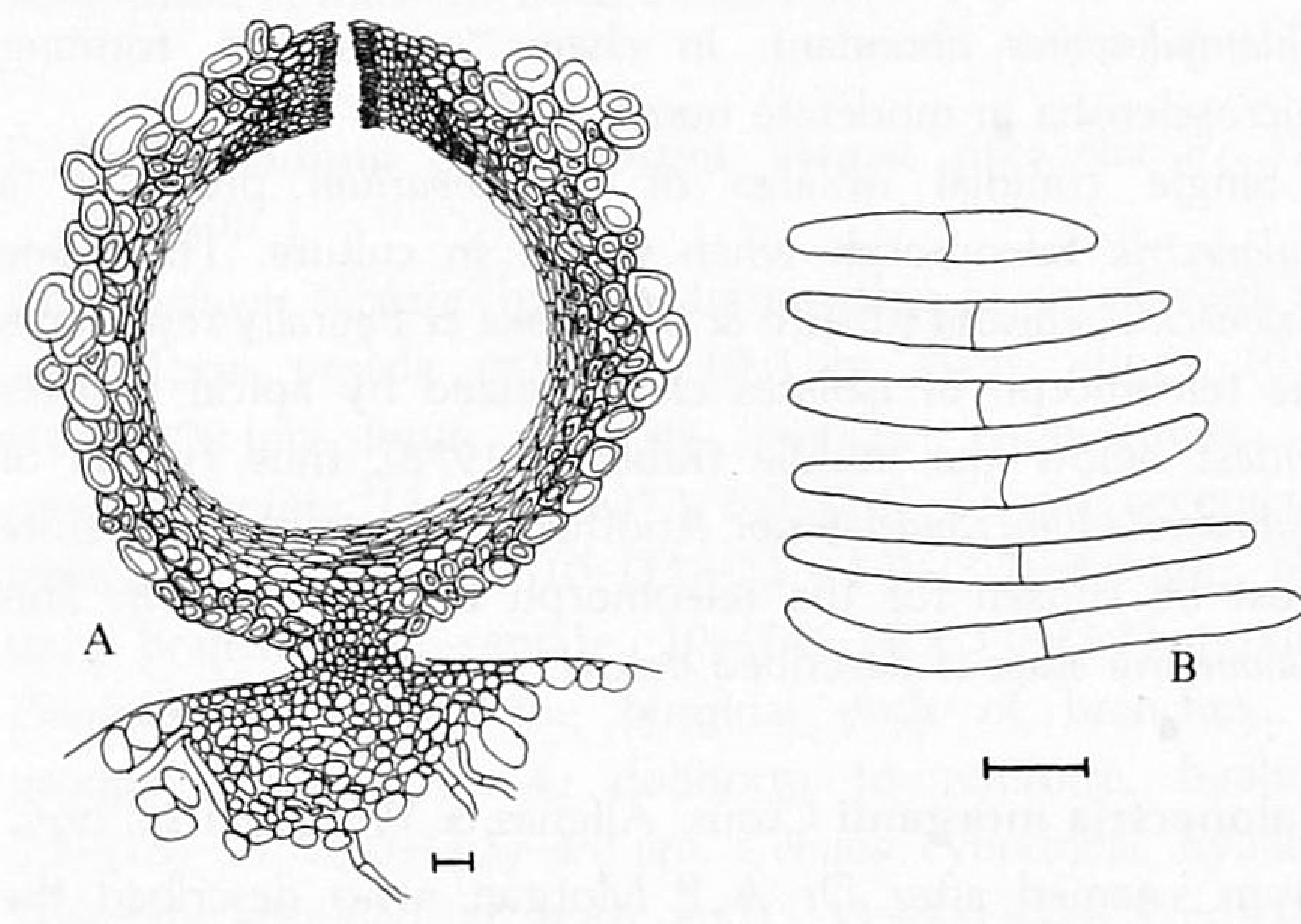

Fig. 4. Calonectria scoparia (paired Brazilian and South African isolates PPRI $4153 \times$ PPRI 4198). A, Vertical section through a perithecium (bar $=20 \mu \mathrm{m}) ; B$, ascospores $($ bar $=10 \mu \mathrm{m})$.

isolate (ATCC 46300) (+) was interfertile with the Brazilian isolate PPRI 4731 ( - ) of C. scoparium.

The perithecia resulting from compatible pairings amongst Brazilian isolates of $C$. candelabrum were larger and more elongated than those from pairings between the South African isolates. The latter structures tended to be globose. Furthermore, cells on the outer layer of perithecia from pairings amongst Brazilian isolates were smaller and the ascospores longer and narrower than those from pairings amongst South African isolates. Pairings between Brazilian and South African isolates of $C$. candelabrum resulted in the formation of perithecia and ascospores of a size more typical of the larger Brazilian than the smaller South African progeny (Figs 4, 5).

\section{Total protein electrophoresis}

South African isolates assigned the name C. candelabrum had uniform protein banding patterns, which were distinct from those of North American isolates of C. scoparium. However, Brazilian isolates of $C$. candelabrum showed much more variation than those from South Africa.

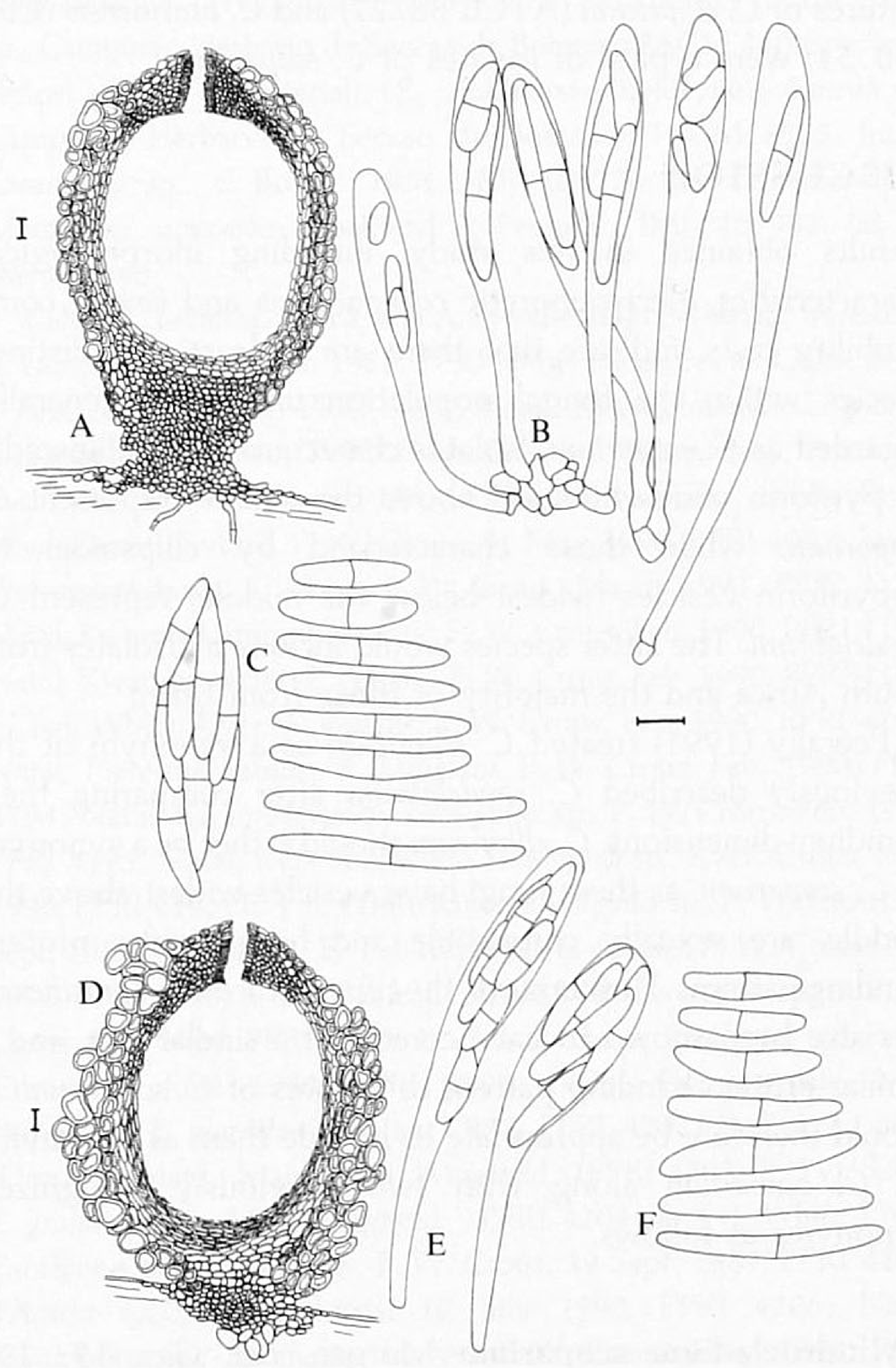

Fig. 5. Calonectria scoparia. A, Vertical section through a perithecium (bar $=20 \mu \mathrm{m}) ; B$, immature and mature asci; C, ascospores (paired Brazilian isolates PPRI $4163 \times$ PPRI $4153, \mathrm{bar}=10 \mu \mathrm{m})$; $\mathrm{D}$, vertical section through a perithecium ( $b a r=20 \mu \mathrm{m}$ ); $\mathrm{E}$, ascospores (paired South African isolates PPRI $4202 \times$ PPRI 4199, bar $=10 \mu \mathrm{m}$ ).

Isolates could be placed in either $C$. scoparium or $C$. candelabrum based on their vesicle morphologies and could also be distinguished by means of their protein banding patterns (Fig. 6). North American and Brazilian isolates typical 


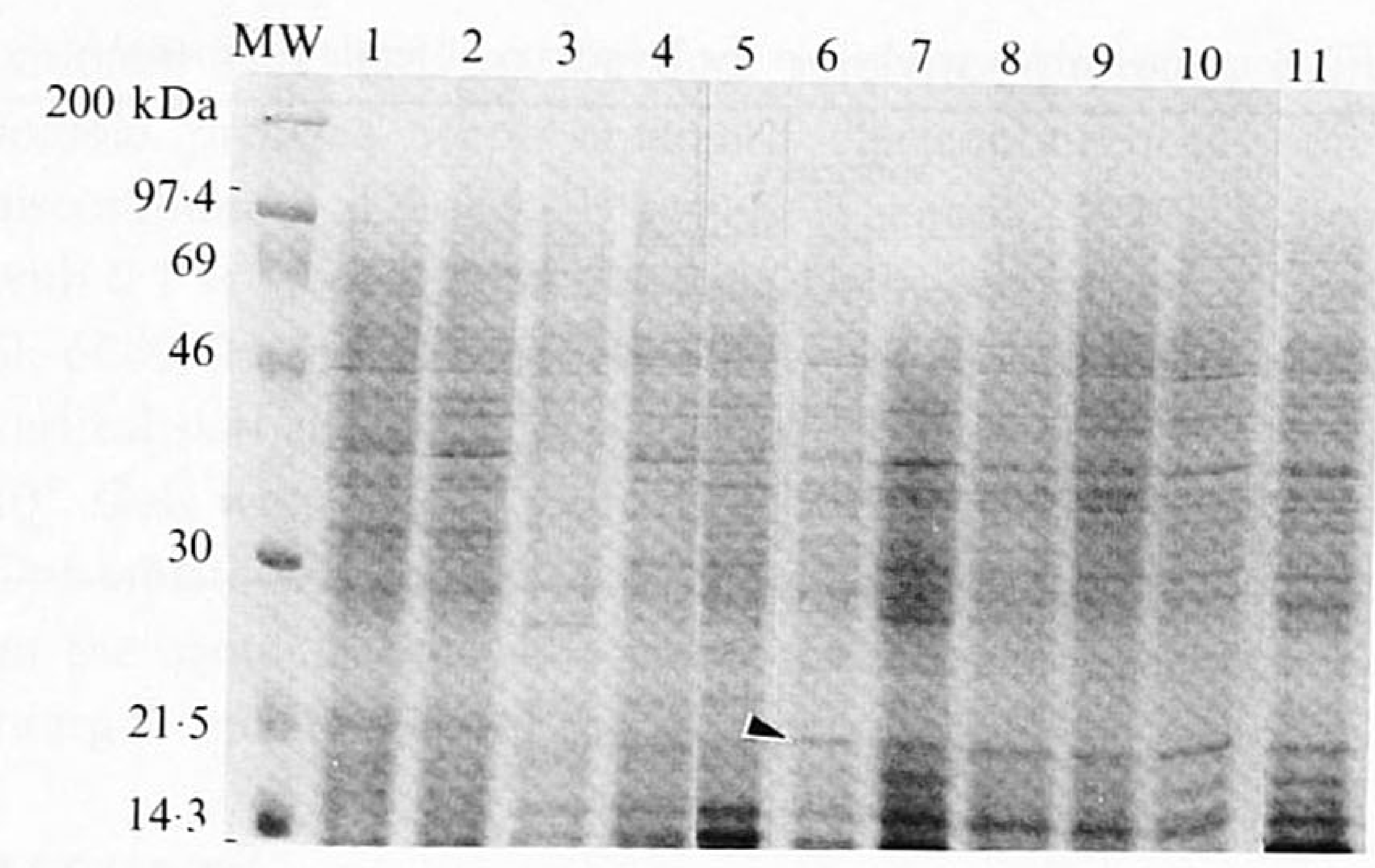

Fig. 6. SDS electrophoresis gel of Cylindrocladium candelabrum and C. scoparium isolates. Molecular weights $(\mathrm{mw})$ are given in kilodaltons, while data pertaining to the isolates are given in Table 1. Arrow indicates a distinct band present in isolates of $C$. scoparium, but absent in those of C. candelabrum.

of C. scoparium had a distinct band in the vicinity of $21.5 \mathrm{kDa}$, which was missing in South African and Brazilian isolates typical of $C$. candelabrum. The banding patterns of the type cultures of C. ellipticum (ATCC 38227) and C. brasiliensis (CBS 230.51 ) were typical of isolates of C. scoparium.

\section{DISCUSSION}

Results obtained in this study, including morphological characteristics, electrophoretic comparisons and sexual compatibility tests, indicate that there are at least two distinct species within the fungal population until now generally regarded as C. scoparium. Isolates characterized by ellipsoidal to pyriform vesicles (widest above the middle) represent $C$. scoparium, while those characterized by ellipsoidal to obpyriform vesicles (widest below the middle) represent $C$. candelabrum. The latter species would include all isolates from South Africa and the majority of those from Brazil.

Peerally (1991) treated C. ellipticum as a synonym of the previously described $C$. candelabrum after comparing their conidium dimensions. C. ellipticum should rather be a synonym of C. scoparium, as these fungi have vesicles widest above the middle, are sexually compatible and have similar protein banding patterns. Furthermore, the type culture of $C$. brasiliensis has also been shown to have conidia of a similar size, and a similar protein banding pattern to isolates of C. scoparium. It would therefore be appropriate to include them as synonyms of C. scoparium along with two previously recognized synonyms as follows.

Cylindrocladium scoparium Morgan, Bot. Gaz. 17: 191 (1892).

Cylindrocladium pithecolobii Petch, Ann. R. Bot. Gard. Peradeniya 6: 244 (1917).

Diplocladium cylindrosporum Ell. \& Everh., Bull. Torrey Bot. Cl. 27: 58 (1900).

Cylindrocladium scoparium var. brasiliensis Batista \& Ciferri, Boletim da S.A.I.C. Pernambuco 18: 190 (1951).

Cylindrocladium brasiliensis (Batista \& Ciferri) Peerally, CMI Descriptions of Pathogenic Fungi and Bacteria No. 427 (1974).
Cylindrocladium ellipticum Alfieri, Seymour \& Sobers, Phytopathology 60: 1213 (1970).

Conidiophores septate, hyaline, terminating in an ellipsoid to pyriform vesicle, 6.0-(6.5)-8.0 $\mu \mathrm{m}$ diam; stipes $150-$ (173)-195 $\mu \mathrm{m}$ long; primary branches non-septate or rarely 1 -septate, $11-(24)-40 \times 4 \cdot 0-(4 \cdot 5)-5 \cdot 0 \mu \mathrm{m}$; secondary branches non-septate, $11-(16)-20 \times(4 \cdot 0)-4.5 \mu \mathrm{m}$; tertiary branches non-septate, $10-(13)-15 \times(4 \cdot 0)-4.5 \mu \mathrm{m}$. Phialides arise from the terminal ends of branches, in groups of 2, 3 or 4 ; doliiform to reniform, hyaline, 9.0-(11)-15 × 3.0-(3.5)$4 \cdot 0 \mu \mathrm{m}$. Conidia cylindrical, hyaline, 1 -septate, rounded at both ends, $40-(44.5)-66 \times 3.5-(4 \cdot 0)-4.5 \mu \mathrm{m}$.

Cultural characteristics. Minimum temperature above $5^{\circ}$; maximum temperature above $35^{\circ}$; optimum temperature range, $25-30^{\circ}$. This is both a high- and a low-temperature species, growing below $10^{\circ}$ and above $30^{\circ}$, with medium sporulation on aerial mycelium. Colony colour (bottom), on MEA after $7 \mathrm{~d}$ in the dark (13K-17'I-15'I), amber brown to buckthorn brown to sayal brown (Rayner, 1970), (5D6-6D8 or 5 C6-6C7) pompeian yellow to light brown, or oak brown to reddish golden (Kornerup \& Wanscher, 1967). Chlamydospores abundant, in chains or clusters, forming microsclerotia in moderate numbers (Fig. 1).

Single conidial isolates of C. scoparium produced a Calonectria teleomorph when paired in culture. The name Calonectria scoparia Ribeiro \& Matsuoka ex Peerally represents the teleomorph of isolates characterized by apical vesicles widest below the middle (Ribeiro, 1978), thus typical of Cylindrocladium candelabrum. Another species epithet therefore must be chosen for the teleomorph of C. scoparium. This Calonectria state is described below.

Calonectria morganii Crous, Alfenas \& Wingfield sp. nov. Etym.: named after Dr A.P. Morgan, who described the genus Cylindrocladium and its type species C. scoparium.

Perithecia superficialia portata, singulatim aut in turmis parvis, globosa vel subglobosa, $280-520 \times 280-400 \mu \mathrm{m}$, rubri-brunnea usque ad rubra, pariete exteriore aspero verrucusoque et ostiolo papillato. Asci hyalini, clavati ad longum et tenuum caulem 75-(80)-100 $\times$ $8 \cdot 0-(10)-15 \mu \mathrm{m}$, capientes $1-8$ ascosporas. Ascosporae hyalinae, rectae vel facatae, 1 -septatae, nihil vel leviter medium ad septum constrictae 24-(37)-49 $\times 4.0-(6.3)-8.0 \mu \mathrm{m}$. Ascosporae evolentes usque ad tres septa dimissae ab asco.

Holotypus: ATCC 46300 (U.S.A., Leucothoe catesbaei) $\times$ PPRI 4731 (Brazil, Anacardium sp.), July 1992, P. W. Crous, PREM 51042 (type specimen).

Perithecia superficial, borne singly or in small groups, globose or subglobose, $280-520 \times 280-400 \mu \mathrm{m}$, red-brown to red, with rough warted outer wall and papillate ostiole (Fig. 1I). Asci hyaline, unitunicate, clavate, $75-(80)-100 \times 8.0-(10 \cdot 0)-$ $15.0 \mu \mathrm{m}$, tapering to a long thin stalk, containing $1-8$ ascospores at maturity (Fig. 1G). Ascospores hyaline, straight to falcate, tapering to rounded ends, 1-septate, smooth, not or slightly constricted at central septum, 24-(37)-49 $\times 4.0$ $(6 \cdot 3)-8 \cdot 0 \mu \mathrm{m}$ (Fig. $1 \mathrm{H}$ ). Ascospores developing up to three septa after discharge from ascus.

Specimens of teleomorph examined: ATCC 46300 (U.S.A., Leucothoe catesbaei) $\times$ PPRI 4731 (Brazil, Anacardium sp.), July 1992, P. W. Crous, PREM 51042 (holotype specimen); ATCC 46300 (U.S.A., 
Leucothoe catesbaei) $\times$ ATCC 38227 (U.S.A., Mahonia bealei), July 1992, P. W. Crous, PREM 51043 (paratype specimen).

Specimens of anamorph examined: Brazil: Recife, Eucalyptus seedlings, A. C. Batista, 11 Sept. 1950, IMI 43688 (ex holotype, C. brasiliensis); U.S.A.: Preston, Ohio, Gleditsia triacanthos, A. P. Morgan, 1893, BPI 414576 (neotype designated here), BPI 414577; Preston, Ohio, Juglans nigra, A. P. Morgan, 1893, BPI 414578.

Cultures examined: Brazil: CE, Fortaleza, Anacardium sp., D. O. Freire, PPRI 4731; T. R. Ciferri, CBS 230.51 ex type of C. brasiliensis (IMI 299576). U.S.A.: Mahonia bealei, S. A. Alfieri, 1970, ATCC 38227 (C. ellipticum, ex type); Florida, Rhododendron sp., C. R. Semer (Viçosa, Brazil, No. UFV 11), PPRI 4144; unknown host, A. Rossman (Viçosa, Brazil, No. UFV 39), PPRI 4154; North Carolina, Leucothoe catesbaei, D. M. Benson, 1981, ATCC 46300; Rosa sp., N. El-Gholl, P90. 1445, PPRI 4732; Florida, Ilex vomitoria, N. El-Gholl, P90.1479, PPRI 4733.

An examination of the type of C. candelabrum found it to be representative of Brazilian and South African isolates with ellipsoidal to obpyriform vesicles. The original description of C. candelabrum is poor and incomplete. Moreover, numerous additional isolates have now been studied, and the species description is thus emended as follows.

\section{Cylindrocladium candelabrum Viegas, Bragantia 6: 370 (1946).}

Conidiophores septate, hyaline, terminating in an ellipsoid to obpyriform vesicle $6.0-(8.0)-10.0 \mu \mathrm{m}$ diam; stipes $105-$ (180)-290 $\mu \mathrm{m}$ long; primary branches non-septate or rarely 1 -septate, $13-(18.5)-27 \times 3.0-(3.5)-4.0 \mu \mathrm{m}$; secondary branches non-septate, $10-(15)-22 \times 3 \cdot 0-(3 \cdot 5)-4 \cdot 0 \mu \mathrm{m}$; tertiary branches non-septate, $10-(14)-16 \times 3 \cdot 0-(3.5)-4.0 \mu \mathrm{m}$. Phialides arise from the terminal ends of branches, in groups of 2,3 or 4 ; doliiform to reniform, hyaline, $7 \cdot 5-(13)-19 \times 3 \cdot 0-(3.5)-4.0 \mu \mathrm{m}$. Conidia cylindrical, hyaline, 1-septate rounded at both ends, 33-(45)-66 $\times 3.5-(4 \cdot 0)-$ $4.5 \mu \mathrm{m}$ (Fig. 2). Temperature requirements for growth and cultural characteristics as for C. scoparium.

Neotype (designated here): Brazil, Copener-Bahia, Eucalyptus sp., A. C. Alfenas, UFV 63, PPRI 4153, PREM 51044 (neotype specimen).

Perithecia of Calonectria scoparia have frequently been found associated with collections of Cylindrocladium candelabrum on Eucalyptus cuttings in forest nurseries in Brazil and South Africa. Furthermore, single-conidial pairings of isolates of C. candelabrum also gave rise to perithecia with a viable progeny. As no holotype specimen could be located in VIC, specimens of the teleomorph collected in this study are briefly described below, and a neotype designated.

Calonectria scoparia Ribeiro \& Matsuoka ex Peerally, Mycotaxon 40: 341 (1991).

Calonectria scoparia Ribeiro \& Matsuoka, Ribeiro, M.Sc. thesis (1978) Heterotalismo em C. scoparium Morgan p. 28. (nom illegit.).

Perithecia superficial, borne singly or in small groups, globose or subglobose, $280-520 \times 280-400 \mu \mathrm{m}$, red-brown to red, with rough warted outer wall and papillate ostiole lined with periphyses. Asci unitunicate, hyaline, clavate, $72-(90)-120 \times 6 \cdot 0-(8.0)-15 \mu \mathrm{m}$, tapering to a long thin stalk, containing 1-8 ascospores at maturity. Ascospores hyaline, straight to falcate, tapering to rounded ends, 1-septate, not or slightly constricted at central septum, 28-(41)-68 $\times$ $4 \cdot 0-(5 \cdot 0)-6 \cdot 5 \mu \mathrm{m}$. Ascospores developing up to three septa after discharge from ascus.

Neotype: Brazil, BA Sul, Picadao, Conceição da Barra, A. C. Alfenas \& F. A. Ferreira, Eucalyptus grandis clone 172 (branch), 27 Apr. 1992, PREM 51045.

Specimens of teleomorph examined. Brazil: BA Sul, Picadao, Conceição da Barra, A. C. Alfenas \& F. A. Ferreira, Eucalyptus grandis clone 172 (branch), 27 Apr. 1992, PREM 51045 (neotype); PPRI 4163 (Eucalyptus sp.) $\times$ PPRI 4153 (Eucalyptus sp.), July 1992, P. W. Crous, PREM 51047; PPRI 4161 (E. grandis) $\times$ PPRI 4153 (Eucalyptus sp.), July 1992, P.W. Crous, PREM 51048; PPRI 4146 (Eucalyptus sp.) $\times$ PPRI 4153 (Eucalyptus sp.), July 1992, P. W. Crous, PREM 51049. Africa: R.S.A., Eastern Transvaal, Sabie, Frankfort, E. grandis cuttings, A. C. Alfenas, 24 Mar. 1992, PREM 51046 (teleomorph occurring naturally on cuttings); PPRI 4202 (E. macarthurii) $\times$ PPRI 4199 (Eucalyptus sp.), July 1992, P. W. Crous, PREM 51050.

Specimens of anamorph examined. Africa: Kenya, E. saligna Sm., I. Gibson, 1966, IMI 123734; R.S.A., Natal, Cedara, Syncarpia gummifera, M. J. Wingfield, 17 July 1978, PPRI 45419. Brazil: Luma sp., Campinas, Herbario da Seccao de Botanico IACM 440 (specimen almost devoid of material). (C. candelabrum, holotype); Annona sp., Campinas, Herbario da Seccao de Botanico, IACM 8155. India: Eucalyptus sp., C. Booth, 1964, IMI 108770 (as C. theobromae) Mauritius: unknown host, M. A. Peerally, IMI 167982 (as C. sclerotiorum).

Cultures examined. Africa: R.S.A.: Swellendam, Medicago truncatula, S. Lamprecht, 16 March 1986, PPRI 3554; Natal, Seven Oaks, debri, I Feb. 1990, I. Rong, PPRI 3812; Natal, Kwambonambi, E. grandis, G. Kemp, May 1990, PPRI 3988; E[astern] T[rans]v[aa]l, Frankfort, Eucalyptus sp., S. H. Koch, 1988, PPRI 3989; E. Tvl, White River, Rhododendron hybrid, P. W. Crous, 11 May 1990, PPRI 4085; Natal, Pietermaritzburg, E. nitens, P. W. Crous, March 1991, PPRI 4189; Natal, Kwambonambi, E. grandis, P. W. Crous, Feb. 1990, PPRI 4191; Natal, Kwambonambi, E. grandis, P. W. Crous, Feb. 1990, PPRI 4192; E. Tvl, White River, E. grandis, P. W. Crous, Feb. 1990, PPRI 4193; Natal, Pietermaritzburg, E. fastigiata, P. W. Crous, Feb. 1990, PPRI 4194; Natal, Kwambonambi, Eucalyptus sp., P. W. Crous, Feb. 1990, PPRI 4195; Natal, Kwambonambi, Eucalyptus sp., P. W. Crous, May 1990, PPRI 4196; E. Tvl, White River, Eucalyptus sp., P. W. Crous, 29 Sept. 1989, PPRI 4197; E. Tvl, Klipkraal, E. grandis, P. W. Crous, Feb. 1990, PPRI 4198; E. Tvl, Sabie, D. R. De Wet, Eucalyptus roots, P. W. Crous, Feb. 1990, PPRI 4199; N. Tvl, Tzaneen, Eucalyptus sp., P. W. Crous, 28 June 1990, PPRI 4201; Natal, Commondale, M. J. Wingfield, E. macathurii, 5 Jan. 1987, PPRI 4202; E. Tvl, E. nitens (Deane \& Maid.) Maid., M. J. Wingfield, ?PPRI 4203; E. Tvl, Sabie, E. grandis roots, M. J. Wingfield, ?PPRI 4204; E. Tvl, White River, Eucalyptus grandis cuttings, P. W. Crous, 29 Sept. 1989, PPRI 4205; ?Acacia cyclops, M. Morris, 10 July 1990, PPRI 4206; Natal, Kwambonambi, Eucalyptus leaves, P. W. Crous, May 1990, PPRI 4208. Brazil: MG, João Pinheiro, E. cloeziana, A. C. Alfenas, PPRI 4151; MG, Virginopolis, Eucalyptus sp., PPRI 4146; ?UNB, J. C. Dianese, PPRI 4147; Copener-Bahia, Eucalyptus sp., PPRI 4148; UNB, J.C. Dianese, PPRI 4149; Viveiro, Eucalyptus sp., A. C. Alfenas, PPRI 4150; Copener-Bahia, Eucalyptus sp., A. C. Alfenas, PPRI 4152; Copener-Bahia, Eucalyptus sp., A. C. Alfenas, PPRI 4153; ?UNB, J. C. Dianese, PPRI 4155; CAF, Eucalyptus sp., A. C. Alfenas, PPRI 4156; MG, Ipatinga, Eucalyptus sp., A. C. Alfenas, PPRI 4158; MG, Ipatinga, Eucalyptus sp., A.C. Alfenas, PPRI 4159; Viveiro Florestas Rio Doce, E. grandis, A. C. Alfenas, PPRI 4161; ?UNB, C. J. Dianese, PPRI 4162; MG, Coronel Fabricano, Eucalyptus sp., A. C. 
Alfenas, PPRI 4163; PE, Recife, Eucalyptus sp., R. L. R. Mariano, PPRI 4165; ES, Aracruz, Eucalyptus sp., A. C. Alfenas, UFV 117, PPRI 4734 .

The present study has shown that the name $C$. scoparium has become a repository for fungi representing at least two species distinguishable on their vesicle morphology and sexual compatibility. A substantial collection of isolates from North America, Brazil and South Africa has been considered. It seems likely that additional collections of isolates from other parts of the world, currently accommodated within the broader C. scoparium species concept, might include additional species.

We thank the curators of the American Type Culture Collection (ATCC, Parklawn Drive, Rockville, U.S.A.), International Mycological Institute (IMI, Bakeham Lane, Egham, Surrey, U.K.), Beltsville, Agricultural Research Centre (BPI, Maryland, U.S.A.) and Herbario da Seccao de Botanico (IACM, Campinas, Brazil) for placing their material and cultures at our disposal. We are also grateful to Dr Amy Rossman (BPI) for useful comments on an earlier version of this paper.

\section{REFERENCES}

Alfenas, A. C., Matsuoka, K., Ferreira, F. A. \& Hodges, C. S. (1979). Identification, cultural characteristics and pathogenicity of three species of Cylindrocladium isolated from leaf spots of Eucalyptus spp. Fitopatologia Brasileira 4, 445-459.

Alfieri, S. A., Seymour, C. P. \& Sobers, E. K. (1970). Brown leaf necrosis of Mahonia bealei caused by Cylindrocladium ellipticum species nova. Phytopathology 60, 1212-1215.

Batista, A. C. (1951). Cylindrocladium scoparium Morgan var. brasiliensis Batista \& Ciferri, a new fungus on Eucalyptus. Boletim da Secretaria de agricultura, industria e comercio do Estado de Pernambuco 18, 188-191.

Bertus, A. L. (1976). Cylindrocladium scoparium Morgan on Australian native plants in cultivation. Phytopathologische Zeitschrift 85, 15-25.

Booth, C. \& Gibson, I. A.S. (1973). Cylindrocladium scoparium. CMI Descriptions of Pathogenic Fungi and Bacteria no. 362.

Cordell, C. E. \& Rowan, S. J. (1975). Cylindrocladium scoparium infection in a natural sweetgum stand. Plant Disease Reporter 59, 775-776.

Cordell, C. E. \& Skilling, D. D. (1975). Forest nursery diseases in the USA. 7. Cylindrocladium root rot. U.S.D.A. Forest Service Agriculture Handbook no. 470.
Crous, P. W., Phillips, A. J. L. \& Wingfield, M. J. (1992). Effects of cultural conditions on vesicle and conidium morphology in species of Cylindrocladium and Cylindrocladiella. Mycologia 84, 497-504.

El-Gholl, N. E., Kimbrough, J. W., Barnard, E. L., Alfieri, S. A. \& Schoulties, C. L. (1986). Calonectria spathulata sp. nov. Mycotaxon 26, 151-164.

El-Gholl, N. E., Leahy, R. M. \& Schubert, T.S. (1989). Cylindrocladium leucothoeae sp. nov. Canadian Journal of Botany 67, 2529-2532.

Ferreira, F. A. (1989). Patologia Florestal. Principais doenças florestais no Brasil. Viçosa, Sociedade de Investigações Florestais: Brasil.

Fisher, N. L., Burgess, L. W., Toussoun, T. A. \& Nelson, P. E. (1982). Carnation leaves as a substrate and for preserving cultures of Fusarium species. Phytopathology 72, 151-153.

French, D. W. \& Menge, J. A. (1978). Survival of Cylindrocladium floridanum in naturally and artificially infested forest tree nurseries. Plant Disease Reporter 62, 806-810.

Hodges, C. S. \& May, L. C. (1972). A root disease of pine, Araucaria, and Eucalyptus in Brazil caused by a new species of Cylindrocladium. Phytopathology 62, 898-901.

Holmgren, P. K. \& Keuken, W. (1974). Index Herbariorum Part 1. The herbaria of the world. Regnum Vegetabile 92.

Hunter, B. B. \& Barnett, H. L. (1978). Growth and sporulation of species and isolates of Cylindrocladium in culture. Mycologia 70, 614-635.

Kornerup, A. \& Wanscher, J. H. (1967). Methuen Handbook of Colour, 2nd edn, Methuen: London.

Laemmli, U.K. (1970). Cleavage of structural proteins during the assembly of the head of bacteriophage T4. Nature 227, 680-685

Morgan, A. P. (1892). Two new genera of Hyphomycetes. Botanical Gazette (Crawfordsville) 17, 190-192.

Peerally, A. (1973). Calonectria colhounii sp. nov. a common parasite of tea in Mauritius. Transactions of the British Mycological Society 61, 89-93.

Peerally, A. (1991). The classification and phytopathology of Cylindrocladium species. Mycotaxon 40, 323-366.

Rayner, R. W. (1970). A Mycological Colour Chart. CMI and British Mycological Society: Kew, Surrey, England.

Ribeiro, J. O. (1978). Heterotalismo em Cylindrocladium scoparium Morgan. M.Sc. thesis, Universidade Federal de Viçosa

Rossman, A. Y. (1983). The phragmosporous species of Nectria and related genera. Mycological Papers 150, 1-164.

Sobers, E. K. (1968). Morphology and host range of Cylindrocladium pteridis. Phytopathology 58, 1265-1270.

Sobers, E. K. (1974). The Calonectria state of Cylindrocladium scoparium. Phytopathology 63, 448 (Abstr.).

Sobers, E. K. \& Seymour, C. P. (1967). Cylindrocladium floridanum sp. nov associated with decline of peach trees in Florida. Phytopathology, 57, 389-393.

Viegas, A. P. (1946). Alguns fungos do Brasil. 8. Bragantia 6, 353-442.

Zumpetta, G. M. (1976). An electrophoretic study of the genus Cylindrocladium as a possible taxonomic tool. M.Sc. thesis, California State College, California, Pennsylvania. 